\title{
Correction to: Perspectives and pregnancy outcomes of maternal Ramadan fasting in the second trimester of pregnancy
}

\author{
Kolsoom Safari ${ }^{1 *}$, Tiran Jamil Piro ${ }^{1}$ and Hamdia Mirkhan Ahmad $^{2}$
}

Correction to: BMC Pregnancy Childbirth (2019) 19:

128

https://doi.org/10.1186/s12884-019-2275-x

Following publication of the original article [1], the author notified us about the incorrect values on Table 4 .

The true Odds for gestational diabetes (GDM) is 0.2 not 1.51. Therefore, in addition to correcting the values for OR in the Table 4, the following sentence in the published article:

Women who did not fast during the second trimester of pregnancy were 1.51 times more likely to develop gestational diabetes.

Should be replaced by:

Women who fasted during the second trimester of pregnancy were 0.8 times less likely to develop gestational diabetes.

Correcting the OR value will not affect other part of the study in any way. It also prevents misinterpretation of our findings, and clearly shows the main result of this study "negative relationship between fasting during pregnancy and risk of GDM", which is approved by other tests used in this study.

The authors apologize for any inconvenience caused by this error.

\section{Author details}

${ }^{1}$ Department of Midwifery, College of Nursing, Hawler Medical University, Erbil, Iraq. ${ }^{2}$ Department of Basic Science, College of Basic Science, Hawler Medical University, Erbil, Iraq.
Published online: 09 December 2019

Reference

1. Safari, et al. BMC Pregnancy Childbirth. 2019;19:128. https://doi.org/10.1186/ s12884-019-2275-x.

The original article can be found online at https://doi.org/10.1186/s12884$019-2275-x$

* Correspondence: kolsoom.safari@hmu.edu.krd

'Department of Midwifery, College of Nursing, Hawler Medical University, Erbil, Iraq

Full list of author information is available at the end of the article

(c) The Author(s). 2019 Open Access This article is distributed under the terms of the Creative Commons Attribution 4.0 International License (http://creativecommons.org/licenses/by/4.0/), which permits unrestricted use, distribution, and reproduction in any medium, provided you give appropriate credit to the original author(s) and the source, provide a link to the Creative Commons license, and indicate if changes were made. The Creative Commons Public Domain Dedication waiver (http://creativecommons.org/publicdomain/zero/1.0/) applies to the data made available in this article, unless otherwise stated. 
Table 4 Unadjusted and adjusted relationship of pregnancy outcome with fasting behaviors

\begin{tabular}{|c|c|c|c|c|}
\hline & \multicolumn{2}{|l|}{ Unadjusted } & \multicolumn{2}{|l|}{ Adjusted } \\
\hline & OR $(95 \% \mathrm{Cl})$ & $P$ value & OR $(95 \% \mathrm{Cl})$ & $P$ value \\
\hline \multicolumn{5}{|l|}{ - Type of birth } \\
\hline - Vaginal delivery & $0.93\left(0.83 \_1.05\right)$ & 0.2 & $0.92\left(0.82 \_1.05\right)$ & 0.24 \\
\hline \multicolumn{5}{|l|}{ - Cesarean section } \\
\hline - Gestational diabetes mellitus & $0.26\left(0.07 \_0.8\right)$ & 0.02 & $0.2\left(0.06 \_0.74\right)$ & 0.01 \\
\hline - Preterm labour & $0.68\left(0.33 \_4.42\right)$ & 0.7 & $0.8\left(0.32 \_4.4\right)$ & 0.79 \\
\hline - Preeclampsia & $0.9\left(0.51 \_2.09\right)$ & 0.9 & $0.91\left(0.49 \_2.04\right)$ & 0.98 \\
\hline - Low birth weight & $1.1\left(0.45 \_8.01\right)$ & 0.38 & $1.1\left(0.44 \_7.86\right)$ & 0.39 \\
\hline - Birth weight & $0.6\left(0.68 \_1.16\right)$ & 0.39 & $0.1\left(0.7 \_1.15\right)$ & 0.41 \\
\hline - Birth height & $1.04\left(0.94 \_1.11\right)$ & 0.49 & $1\left(0.94 \_1.12\right)$ & 0.45 \\
\hline - Head circumference & $0.89\left(0.78 \_1.01\right)$ & 0.07 & $0.9\left(0.79 \_1.02\right)$ & 0.11 \\
\hline - 5th minutes Apgar score & $1.03\left(0.7 \_1.36\right)$ & 0.9 & $0.9\left(0.72 \_1.34\right)$ & 0.92 \\
\hline
\end{tabular}

All models adjusted for age, maternal education, maternal occupation, number of para, and BMI before pregnancy 